\title{
Retrieval of ammonia from ground-based FTIR solar spectra
}

\author{
E. Dammers ${ }^{1}$, C. Vigouroux ${ }^{2}$, M. Palm ${ }^{3}$, E. Mahieu ${ }^{4}$, T. Warneke ${ }^{3}$, D. Smale ${ }^{5}$, B. Langerock ${ }^{2}$, B. Franco ${ }^{4}$, \\ M. Van Damme ${ }^{1,6}$, M. Schaap ${ }^{7}$, J. Notholt ${ }^{3}$, and J. W. Erisman ${ }^{1,8}$ \\ ${ }^{1}$ Cluster Earth and Climate, Department of Earth Sciences, Vrije Universiteit Amsterdam, Amsterdam, the Netherlands \\ ${ }^{2}$ Belgian Institute for Space Aeronomy, Brussels, Belgium \\ ${ }^{3}$ Institut für Umweltphysik, University of Bremen, Bremen, Germany \\ ${ }^{4}$ Institute of Astrophysics and Geophysics, University of Liege, Belgium \\ ${ }^{5}$ National Institute of Water and Atmosphere, Lauder, New Zealand \\ ${ }^{6}$ Spectroscopie de l'Atmosphère, Service de Chimie Quantique et Photophysique, \\ Université Libre de Bruxelles, Brussels, Belgium \\ ${ }^{7}$ TNO Built Environment and Geosciences, Department of Air Quality and Climate, Utrecht, the Netherlands \\ ${ }^{8}$ Louis Bolk Institute, Driebergen, the Netherlands \\ Correspondence to: E. Dammers (e.dammers@vu.nl)
}

Received: 1 June 2015 - Published in Atmos. Chem. Phys. Discuss.: 28 August 2015

Revised: 6 November 2015 - Accepted: 9 November 2015 - Published: 18 November 2015

\begin{abstract}
We present a retrieval method for ammonia $\left(\mathrm{NH}_{3}\right)$ total columns from ground-based Fourier transform infrared (FTIR) observations. Observations from Bremen $\left(53.10^{\circ} \mathrm{N}\right.$, $\left.8.85^{\circ} \mathrm{E}\right)$, Lauder $\left(45.04^{\circ} \mathrm{S}, 169.68^{\circ} \mathrm{E}\right)$, Réunion $\left(20.9^{\circ} \mathrm{S}\right.$, $\left.55.50^{\circ} \mathrm{E}\right)$ and Jungfraujoch $\left(46.55^{\circ} \mathrm{N}, 7.98^{\circ} \mathrm{E}\right)$ were used to illustrate the capabilities of the method. $\mathrm{NH}_{3}$ mean total columns ranging 3 orders of magnitude were obtained, with higher values at Bremen (mean of $13.47 \times$ $10^{15}$ molecules $\mathrm{cm}^{-2}$ ) and lower values at Jungfraujoch (mean of $0.18 \times 10^{15}$ molecules $\mathrm{cm}^{-2}$ ). In conditions with high surface concentrations of ammonia, as in Bremen, it is possible to retrieve information on the vertical gradient, as two layers can be distinguished. The retrieval there is most sensitive to ammonia in the planetary boundary layer, where the trace gas concentration is highest. For conditions with low concentrations, only the total column can be retrieved. Combining the systematic and random errors we have a mean total error of $26 \%$ for all spectra measured at Bremen (number of spectra $(N)=554$ ), $30 \%$ for all spectra from Lauder ( $N=2412), 25 \%$ for spectra from Réunion $(N=1262)$ and $34 \%$ for spectra measured at Jungfraujoch $(N=2702)$. The error is dominated by the systematic uncertainties in the spectroscopy parameters. Station-specific seasonal cycles were found to be consistent with known seasonal cycles of the dominant ammonia sources in the station surroundings. The developed retrieval methodology from FTIR
\end{abstract}

instruments provides a new way of obtaining highly timeresolved measurements of ammonia burdens. FTIR-NH $\mathrm{NH}_{3}$ observations will be useful for understanding the dynamics of ammonia concentrations in the atmosphere and for satellite and model validation. It will also provide additional information to constrain the global ammonia budget.

\section{Introduction}

Nitrogen emissions in the form of ammonia $\left(\mathrm{NH}_{3}\right)$, which largely derive from agriculture, have been associated with acidification and eutrophication of soils and surface waters (Krupa, 2003; Vitousek et al., 1997), which may reduce biodiversity in vulnerable ecosystems (Bobbink et al., 1998, 2010). Ammonia also reacts with nitric acid and sulfuric acid to form ammonium salts, which account for a large fraction of particulate matter concentrations (Schaap et al., 2004). Particulate matter is a major contributor to smog and is related to negative health impacts (Pope III et al., 2009). Moreover ammonium salts play an important role in the radiance balance of the Earth, thus having an impact on climate change (Charlson et al., 1991; Erisman et al., 2007). It has been shown that reduced nitrogen also plays a role in the fixation of carbon dioxide $\left(\mathrm{CO}_{2}\right)$ (Reay et al., 2008). Human activities have increased the global emissions 
of reactive nitrogen $(\mathrm{Nr})$ to the atmosphere (Holland et al., 1999). Current global $\mathrm{Nr}$ emissions have been estimated to be almost 4 times larger than pre-industrial levels (Fowler et al., 2013), with $\mathrm{NH}_{3}$ emissions amounting to $49.3 \mathrm{Tg}$ in 2008 (EDGAR - Emission Database for Global Atmospheric Research, 2011). Consequently this has led to large increases in atmospheric nitrogen deposition (Rodhe et al., 2002; Dentener et al., 2006). Biomass burning was found to account for $11 \%$ of the global emission budget of $\mathrm{NH}_{3}$ (Bouwman et al., 1997). While agricultural emissions dominate in the Northern Hemisphere, biomass burning is one of the main sources of $\mathrm{NH}_{3}$ concentration in the Southern Hemisphere.

Despite its central role in many environmental threats, little is known about the ammonia budget and its distribution across the globe. Uncertainties in global and regional emission rates are large, with errors of more than $50 \%$ (Erisman et al., 2007; Sutton et al., 2013). Ammonia concentrations have a large variability in time and space and a short lifetime in the order of hours. The lack of globally distributed observations hampers our understanding. Surface observations are available, but these are not homogenously distributed over the globe, with most observation sites located in the Northern Hemisphere. Most sites provide data with a poor temporal resolution (e.g. many observation networks use passive samplers with a sampling time of 2 or 4 weeks (Thijsse et al., 1998; Puchalski et al., 2011)), whereas emission and deposition dynamics affect concentrations on the scale of hours to days. Systems with higher sampling frequency such as the AMANDA, MARGA and (denuder) filter packs are available, but the number of measurement networks using these instruments is limited as they are often costly to operate (Erisman et al., 2001; Thomas et al., 2009; Mount et al., 2002; Hansen et al., 2003). Moreover, measuring $\mathrm{NH}_{3}$ is challenging and existing in situ measurement techniques are often prone to sampling artefacts (von Bobrutzki et al., 2010). Recent advances in open-path remote sensing techniques, like (mini-)differential optical absorption spectroscopy (DOAS) systems and open-path quantum cascade laser (QCL) instruments, show great potential in overcoming part of these sampling issues (Volten et al., 2012; Miller et al., 2014), but are still in the development stage and not widely applied yet. Another aspect is the lack of vertical information, as most instruments only measure surface concentrations (Erisman et al., 2007, 2008; Van Damme et al., 2015a). Some recent airborne measurements have been made (Nowak et al., 2007, 2010; Leen et al., 2013), but only during dedicated campaigns with limited temporal and spatial coverage. In short, it is very difficult to obtain detailed knowledge on the global ammonia budget using field observations that are currently available.

Remote sensing products from atmospheric satellite sounders such as the Infrared Atmospheric Sounding Interferometer (IASI), the Tropospheric Emission Spectrometer (TES) and the Cross-track Infrared Sounder (CrIS) (Van Damme et al., 2014a; Shephard et al., 2011, 2015) have be- come available and show good promise to improve $\mathrm{NH}_{3}$ concentration monitoring (Van Damme et al. 2014b; Luo et al., 2015; Whitburn et al., 2015). However, these data sets are constrained by the overpass time of the satellite and the atmospheric conditions (cloud coverage, thermal contrast, etc.). Moreover, the uncertainties associated to the data are relatively large, which calls for a detailed evaluation of the data. A recent study (Van Damme et al., 2015a) showed a number of challenges related to the validation. First, reliable hourly in situ data are sparse. Second, when not using optimal estimation satellite products, as is the case for the IASI-NH retrieval, one has to assume a vertical profile to link surface concentrations to a column value. Third, the ground-based observations are often influenced by local sources, whereas satellite observations have a footprint of the order of tens of kilometres. A recent study by Shephard et al. (2015) shows the potential of an instrument that can be used for profile comparisons. In the study, instruments on an aircraft were used to measure a vertical profile of $\mathrm{NH}_{3}$; these measurements were used as a validation tool for the $\mathrm{NH}_{3}$-profile observations of TES. Hence, a measurement methodology that provides columnar and vertical profiles of ammonia concentrations at a high temporal resolution would be highly beneficial for evaluating the merits of the novel satellite products. Fourier transform infrared spectrometry (FTIR) provides this methodology. Atmospheric sounders have a long history for validation of satellite products. FTIR observations are already commonly used for the validation of satellite products of, among others, carbon monoxide (CO), methane $\left(\mathrm{CH}_{4}\right)$ and nitrous oxide $\left(\mathrm{N}_{2} \mathrm{O}\right)$ (Wood, 2002; Griesfeller et al., 2006; Dils et al., 2006; Kerzenmacher et al., 2012).

FTIR spectrometry is a well-established remote sensing technique for the observation of atmospheric trace gases (Rao and Weber, 1992). FTIR has so far been used to estimate ammonia emissions from fires (Yokelson et al., 1997, 2007; Paton-Walsh et al., 2005), but only on a campaign basis, not through long-term monitoring. There are several monitoring stations with FTIR instruments that are operated on a regular basis, providing long-term time series for a suite of key tropospheric and stratospheric species, including carbon dioxide $\left(\mathrm{CO}_{2}\right)$, carbon monoxide $(\mathrm{CO})$ and ozone $\left(\mathrm{O}_{3}\right)$. So far nobody has systematically analysed the FTIR measurements for $\mathrm{NH}_{3}$. We have developed a $\mathrm{NH}_{3}$-retrieval strategy for four Network for the Detection of Atmospheric Composition Change (NDACC) FTIR stations, spanning very different concentration conditions (polluted and remote sites), in order to obtain time series of $\mathrm{NH}_{3}$ total columns and show their value for describing temporal variations.

First we present the measurement sites and the retrieval strategies in Sect. 2. We describe the characteristics of the retrieval in Sect. 3.1.1 and the uncertainty budget in Sect. 3.1.2. Section 3.2 constitutes of an interpretation of the results in combination with a comparison with existing data sets of $\mathrm{CO}$ total columns and temperature to distinguish between emission sources. We summarize the results in Sect. 4. 


\section{Measurement sites and retrieval strategies}

\subsection{Sites description}

Ground-based FTIR instruments measure the solar absorption spectra under cloud-free conditions by using a Fourier transform spectrometer. These spectra can be analysed by using a line-by-line model (Pougatchev et al., 1995; Hase et al., 2004, 2006), which models the spectroscopic absorption lines by using known parameters from a spectroscopic database (e.g. HITRAN, Rothman et al., 2013) in combination with the radiative state of the atmosphere, and an optimal estimation inversion scheme (Rodgers, 2000). Information on vertical concentration profiles can be retrieved using the pressure broadening of the absorption lines. For the NDACC network the spectral region measured is the near- to mid-infrared domain ( 740 to $4250 \mathrm{~cm}^{-1}$, i.e. 13.5 to $2.4 \mu \mathrm{m}$ ), with a $\mathrm{HgCdTe}$ or InSb cooled detector (Zander et al., 2008) and a suite of optical filters being used to optimize the signalto-noise ratio in the complementary spectral regions. Instruments in the network are routinely checked and characterized using laboratory measurements of $\mathrm{HBr}$ lines and the line-fit software (Hase et al., 1999) to assess the instrument line shape, alignment and measurement noise levels. Four NDACC stations are used in our study, two in each hemisphere:

- The site of Bremen $\left(53.10^{\circ} \mathrm{N}, 8.85^{\circ} \mathrm{E}\right)$ is especially suitable to measure variations in ammonia concentrations as the surrounding state, Lower Saxony, is a region with intensive agricultural activities with high and temporal variable emissions (Dämmgen and Erisman, 2005). In short, the ammonia total columns (molecules $\mathrm{cm}^{-2}$ ) at Bremen are expected to reach high values compared to background stations. The University of Bremen operates a Bruker 125HR spectrometer and a solar tracker by Bruker $\mathrm{GmbH}$, directly on the university campus.

- The Jungfraujoch station $\left(46.55^{\circ} \mathrm{N}, 7.98^{\circ} \mathrm{E}\right)$ is a highaltitude station ( $3580 \mathrm{~m}$ a.s.l.) located in Switzerland (Zander et al., 2008). There are no sources of large emissions surrounding the station itself as it is located in the free troposphere. At Jungfraujoch, a Bruker 120HR instrument has been in operation since the early 1990s. For the current study, specific for the Jungfraujoch site, we used a subset of spectra recorded during the 20042013 time period with apparent solar zenith angles (SZA) between 70 and $85^{\circ}$ to increase the capability to retrieve the very low ammonia concentrations.

- The Lauder $\left(45.04^{\circ} \mathrm{S}, 169.68^{\circ} \mathrm{E}\right)$ National Institute of Water and Atmospheric Research (NIWA) atmospheric research station in Central Otago, New Zealand, is situated at an altitude of $370 \mathrm{~m}$ a.s.l. Long-term operations started in 1991 with a Bruker 120M (Griffith et al., 2003). This instrument was replaced with a Bruker $120 \mathrm{HR}$ in October 2001. Ammonia emissions in the surrounding valley are mostly due to livestock grazing on the pastures and are a by-product of seasonal fertilizer application. In recent years there has been an increase in cattle grazing and crop cultivation (EDGAR - Emission Database for Global Atmospheric Research, 2011).

- Réunion Island $\left(20.9^{\circ} \mathrm{S}, 55.50^{\circ} \mathrm{E}\right)$ is located in the Indian Ocean to the east of Madagascar. The station is located at the University campus of Saint-Denis on the north side of the island. Agricultural activities are mostly related to sugar cane production. The island is prone to some local biomass burning and wild fire events, which are known to emit ammonia. It is also very close to Madagascar, a region with frequent and intense biomass burning events, and it has been found, using backward trajectory, that the emissions in Madagascar can be transported to Réunion Island within 1 day (Vigouroux et al., 2009). The measurements used in this study are performed with a Bruker $120 \mathrm{M}$ spectrometer. Details on the measurements can be found in Senten et al. (2008) and Vigouroux et al. (2012).

These stations are expected to provide significant differences in variability and levels of ammonia, making them suitable to demonstrate the strength of our retrieval scheme for application across the whole network. A summary of the station descriptions is given in Table 1. CO columns were obtained from the NDACC database to be used for comparison in Sect. 3.

\section{$2.2 \mathrm{NH}_{3}$ retrieval strategies}

The ammonia absorption lines from its $v_{2}$ vibrational band can be observed in the $700-1350 \mathrm{~cm}^{-1}$ wavenumber range and they are also used in the retrieval of satellite products of ammonia (e.g. Clarisse et al., 2009; Van Damme et al., 2014a). In this spectral range the FTIR spectra can be measured using a potassium bromide $(\mathrm{KBr})$ beam splitter in combination with a mercury-cadmium-telluride (MCT) nitrogen-cooled detector (Zander et al., 2008). The retrieval scheme of trace gas concentrations from FTIR spectra is built on the use of a set of spectral micro-windows containing absorption lines of the targeted species, with minimum interference by other atmospheric species or solar lines. Two slightly different sets of spectral micro-windows were used at the four stations, but both sets use the same main $\mathrm{NH}_{3}$ absorption lines. The target and interfering species are summarized in Table 2, with the profile-retrieved species indicated in bold. To properly estimate ammonia, interfering species like $\mathrm{O}_{3}$ and water vapour $\left(\mathrm{H}_{2} \mathrm{O}\right)$ that overlap $\mathrm{NH}_{3}$ lines in the $v_{2}$ vibrational band have to be accounted for. Two micro-windows were chosen that contain as few interfering species as possible. In both sets, the first micro-window (MW1) covers the $\mathrm{NH}_{3}$ absorption line at $930.75 \mathrm{~cm}^{-1}$. At Bremen/Lauder, the 
Table 1. FTIR stations used in the analysis. The location, longitude, latitude and altitude are given for each station as well as the instrument used for the measurements. Some station specifics are given in the last column.

\begin{tabular}{lllllll}
\hline Station & Location & Longitude & Latitude & Altitude $(\mathrm{m}$ a.s.l.) & Instrument & Station specifics \\
\hline Bremen & Germany & $8.85^{\circ} \mathrm{E}$ & $53.10^{\circ} \mathrm{N}$ & 27 & Bruker 125 HR & City, fertilizers, livestock \\
Lauder & New Zealand & $169.68^{\circ} \mathrm{E}$ & $45.04^{\circ} \mathrm{S}$ & 370 & Bruker 120 HR & Fertilizers, livestock \\
Réunion & Indian Ocean & $55.5^{\circ} \mathrm{E}$ & $20.90^{\circ} \mathrm{S}$ & 85 & Bruker 120 M & Fertilizers, fires \\
Jungfraujoch & Switzerland & $7.98^{\circ} \mathrm{E}$ & $46.55^{\circ} \mathrm{N}$ & 3580 & Bruker 120 HR & High altitude, no large sources \\
\hline
\end{tabular}

Table 2. Micro-windows used in the $\mathrm{NH}_{3}$ retrieval at the four stations.

\begin{tabular}{|c|c|c|c|c|}
\hline Stations & Micro-window & Spectral range $\left(\mathrm{cm}^{-1}\right)$ & $\begin{array}{l}\text { Interfering species (profile- } \\
\text { retrieved species in bold) }\end{array}$ & $\begin{array}{l}\text { Signal-to-noise } \\
\text { ratio (SNR) }\end{array}$ \\
\hline \multirow[t]{2}{*}{ Bremen and Lauder } & MW1 & $930.32-931.32$ & $\begin{array}{l}\mathrm{NH}_{3}, \mathbf{H}_{2} \mathbf{O}, \mathbf{O}_{\mathbf{3}}, \mathrm{CO}_{2}, \mathrm{~N}_{2} \mathrm{O}, \\
\mathrm{HNO}_{3}, \mathrm{SF}_{6}, \mathrm{CFC}-12 \text {, solar } \\
\text { lines }\end{array}$ & $\begin{array}{l}\text { Bremen - real } \\
\text { SNR mean value } \\
\text { of } 450\end{array}$ \\
\hline & MW2 & $966.97-967.68$ & $\begin{array}{l}\mathbf{N H}_{\mathbf{3}}, \mathbf{H}_{\mathbf{2}} \mathbf{O}, \mathbf{O}_{\mathbf{3}}, \mathrm{CO}_{2}, \mathrm{~N}_{2} \mathrm{O} \\
\mathrm{HNO}_{3} \text {, solar lines }\end{array}$ & $\begin{array}{l}\text { Lauder }- \text { real } \\
\text { SNR mean value } \\
\text { of } 250\end{array}$ \\
\hline \multirow[t]{2}{*}{ Réunion } & MW1 & 929.4-931.4 & $\begin{array}{l}\mathbf{N H}_{3}, \mathbf{H}_{2} \mathbf{O}, \mathrm{O}_{3}, \mathrm{CO}_{2}, \mathrm{~N}_{2} \mathrm{O} \\
\mathrm{HNO}_{3}, \mathrm{SF}_{6}, \mathrm{CFC}-12\end{array}$ & $\begin{array}{l}\text { Réunion - real } \\
\text { SNR mean value } \\
\text { of } 365\end{array}$ \\
\hline & MW2 & $962.1-970.0$ & $\begin{array}{l}\mathbf{N H}_{3}, \mathbf{H}_{2} \mathbf{O}, \mathrm{O}_{3}, \mathrm{CO}_{2}, \mathrm{~N}_{2} \mathrm{O}, \\
\mathrm{HNO}_{3}, \mathrm{HDO},{ }^{686} \mathrm{O}_{3} \text {, solar } \\
\text { lines }\end{array}$ & \\
\hline \multirow[t]{2}{*}{ Jungfraujoch } & MW1 & 929.4-931.4 & $\begin{array}{l}\mathbf{N H}_{3}, \mathrm{H}_{2} \mathrm{O}, \mathrm{O}_{3}, \mathrm{CO}_{2}, \mathrm{~N}_{2} \mathrm{O}, \\
\mathrm{HNO}_{3}, \mathrm{SF}_{6}, \mathrm{CFC}-12\end{array}$ & \\
\hline & MW2 & $962.1-970.0$ & $\begin{array}{l}\mathbf{N H}_{3}, \mathrm{H}_{2} \mathrm{O}, \mathrm{O}_{3}, \mathrm{CO}_{2}, \mathrm{~N}_{2} \mathrm{O}, \\
\mathrm{HDO},{ }^{66} \mathrm{O}_{3} \text {, solar lines }\end{array}$ & $\begin{array}{l}\text { Jungfraujoch - } \\
\text { fixed at } 250\end{array}$ \\
\hline
\end{tabular}

choice was to use only isolated $\mathrm{NH}_{3}$ absorption features to avoid possible problems due to line mixing, therefore the spectral window MW1 is only $1 \mathrm{~cm}^{-1}$ wide (930.32-931.32; MW1). Figure 1 shows an example of a synthetic spectrum calculated to fit a observation that was measured with the 125HR in Bremen on the 19 April 2010 at 09:59 UTC (solar zenith angle of $45^{\circ}$ ). The $\mathrm{NH}_{3}$ concentrations on this day were slightly higher than average, resulting in slightly stronger $\mathrm{NH}_{3}$ absorption features in the spectra. The top two figures show the absorption contributions of the absorbing species in both micro-windows. The bottom two panels show an enlarged version of the figure to distinguish the interfering species with smaller absorption features. At Réunion Island/Jungfraujoch, MW1 was extended (929.4-931.4; MW1) to cover another $\mathrm{NH}_{3}$ line at $929.9 \mathrm{~cm}^{-1}$. This improved the retrieval for Réunion Island because at this location the $\mathrm{NH}_{3}$ concentration levels are much lower than at Bremen and the water vapour concentrations are much higher. In this high humidity condition, the $930.75 \mathrm{~cm}^{-1}$ line is not isolated from $\mathrm{H}_{2} \mathrm{O}$, and it improved the retrieval to add the more isolated one at $929.9 \mathrm{~cm}^{-1}$ (see Fig. 2). The main interfering species in MW1 are $\mathrm{CO}_{2}, \mathrm{~N}_{2} \mathrm{O}$ and $\mathrm{H}_{2} \mathrm{O}$. Minor interfering species are $\mathrm{SF}_{6}$ and $\mathrm{CFC}-12$. The second window spans the $\mathrm{NH}_{3}$ line at $967.35 \mathrm{~cm}^{-1}$. Again, different widths are used for Bremen/Lauder (966.97-967.68; MW2) and Réunion Island/Jungfraujoch (962.7-970; MW2). The very weak absorption signatures at Réunion Island and Jungfraujoch are close to the noise level and therefore the whole $\mathrm{NH}_{3}$ absorption shape is retrieved (about $964-968 \mathrm{~cm}^{-1}$; see Fig. 2) rather than a single line. The main interfering species in MW2 are $\mathrm{O}_{3}, \mathrm{CO}_{2}$ and $\mathrm{H}_{2} \mathrm{O}$ for all sites. At Réunion Island $\mathrm{HDO}$ also interferes in MW2 as well as the isotopologue ${ }^{686} \mathrm{O}_{3}$ (i.e. ${ }^{16} \mathrm{O}-{ }^{18} \mathrm{O}-{ }^{16} \mathrm{O}$ ), which has been fitted in addition to the main ${ }^{666} \mathrm{O}_{3}$. At Jungfraujoch apart from $\mathrm{CO}_{2}$, two $\mathrm{O}_{3}$ isotopologues (the most abundant and ${ }^{686} \mathrm{O}_{3}$ ) and water vapour, which are the main interferences, $\mathrm{N}_{2} \mathrm{O}, \mathrm{CFC}-12, \mathrm{SF}_{6}$ and $\mathrm{HDO}$ absorptions are also retrieved. Typical $\mathrm{NH}_{3}$ absorptions are weak, on the order of a few tenths of a percent. The typical measurement noise (signal-to-noise ratio) differs per spectra and site but ranges between $\sim 250$ at Lauder and $\sim 450$ at Bremen. Channelling was not an issue in any of the spectra and did not need to be fitted.

Except at Jungfraujoch where SFIT2 is used, the retrieval is performed using the more recent SFIT4.0.9.4 algorithm (Pougatchev et al., 1995; Hase et al., 2004, 2006). Both versions use a form of the optimal estimation method (Rodgers, 2000) to retrieve the volume mixing ratios and total columns of $\mathrm{NH}_{3}$ and make use of a priori information (profile and 

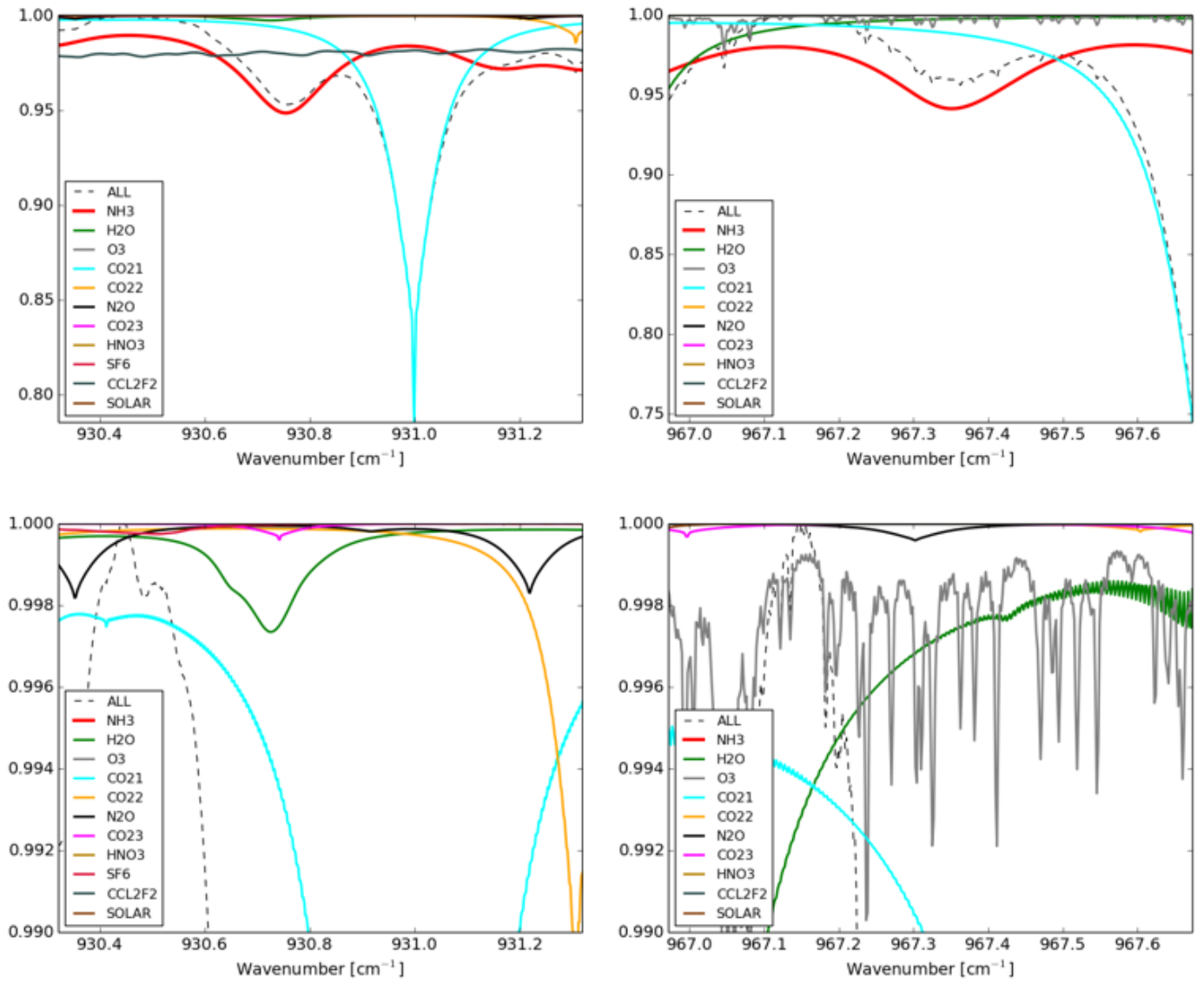

Figure 1. Calculated spectrum for both spectral windows measured with the 125HR in Bremen on the 19 April 2010 at 09:59 UTC, corresponding to a total column of $18.83 \times 10^{15}$ molecules $\mathrm{cm}^{-2}$. The top two panels show the individual contributions of the different species in the first (MW1) and second (MW2) spectral windows. The second row shows the same calculated spectra but now with the y-axis scaled to show the minor interfering species.

covariance matrix). For Bremen, Lauder and Jungfraujoch the used $\mathrm{NH}_{3}$ a priori volume mixing ratios are based on balloon observations (Toon et al., 1999, $\mathrm{NH}_{3}$ available in data set but not reported). The shape of the balloon measurements' profile was kept constant but extended and scaled to expected surface concentrations. The a priori surface volume mixing ratio is estimated to be $10 \mathrm{ppb}$ for Bremen (Dämmgen and Erisman, 2005). Although the shape of $\mathrm{NH}_{3}$ profiles do change through time, the largest share of $\mathrm{NH}_{3}$ is expected to be in the mixing layer, which is represented by the lowest layers in the calculation (Van Damme et al., 2015a; Nowak et al., 2010). At Réunion Island, the a priori profile was taken from the MOZART model (L. Emmons, private communication, 2014). The a priori profile peaks at a higher altitude (4-5 km) instead of the boundary layer as in Bremen, as $\mathrm{NH}_{3}$ is expected to originate mainly from the transport of biomass burning emissions at this location. At all stations, the a priori profiles of the interfering species were taken from the Whole Atmosphere Community Climate Model (Chang et al., 2008).
At Bremen and Lauder, the a priori covariance matrices only have diagonal values, corresponding to standard deviations of $100 \%$ for all layers with no interlayer correlation, chosen in relation to the large range of possible concentrations and variations between layers. At Jungfraujoch and Réunion Island, we did not use the a priori covariance matrix as an optimal estimation; however, the Tikhonov-type $\mathrm{L}_{1}$ regularization (e.g. Sussmann et al., 2009) was adopted for the Jungfraujoch retrievals. After several tests, values of 50 and 250 were adopted for the alpha parameter and the signal to noise for inversion, respectively. A Tikhonov regularization with an alpha parameter value of 50 was also adopted for the Réunion retrievals. The signal to noise ratio is calculated for each of the spectra, the mean value being 365 .

Daily temperature and pressure profiles for the meteorological variables were taken from NCEP (National Centers for Environmental Prediction). For the radiative transfer calculations the profiles were split into about 50 levels, depending slightly on the station, from ground up to $80 \mathrm{~km}(100 \mathrm{~km}$ in the case of Jungfraujoch and Réunion Island). The layers have a typical thickness of $500 \mathrm{~m}$ in the troposphere, up 

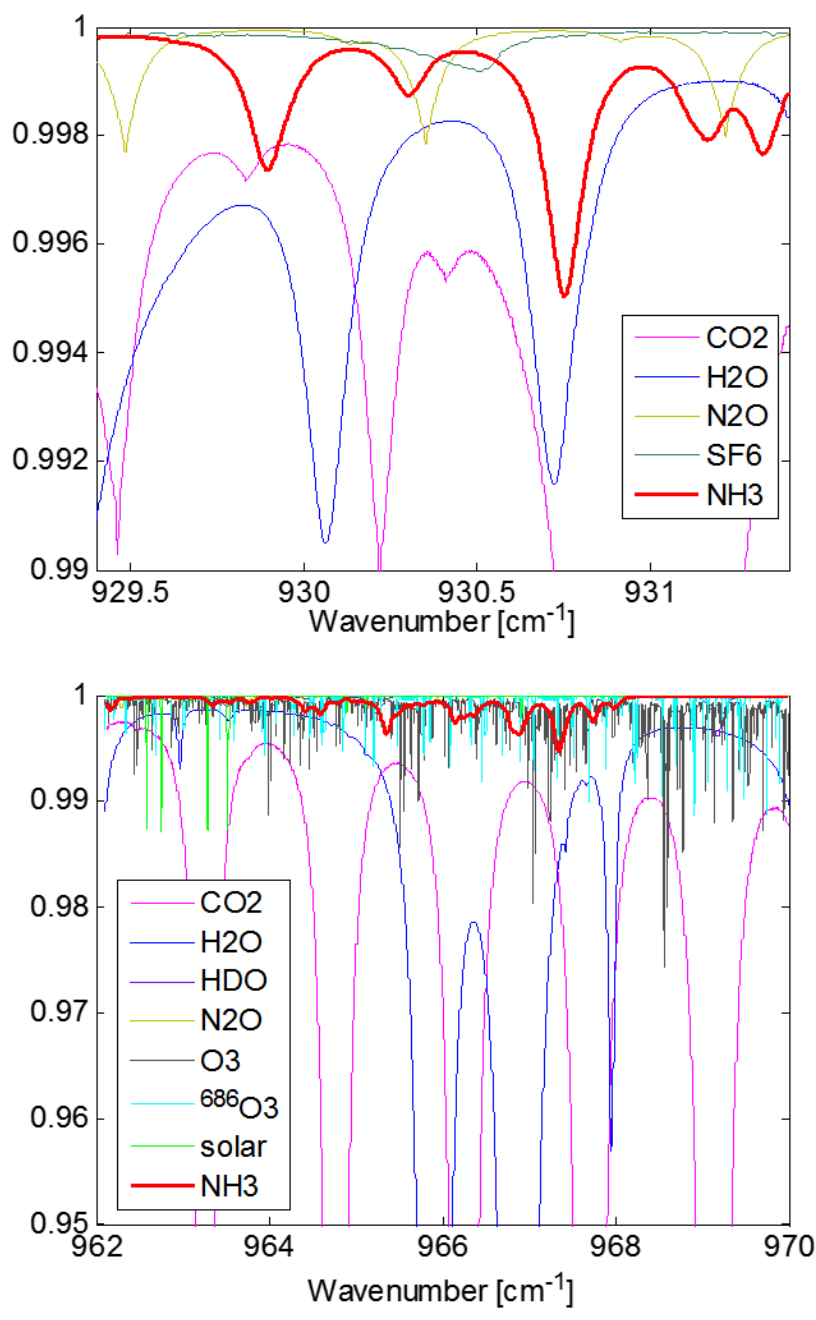

Figure 2. Example of a synthetic atmospheric spectrum for both spectral windows at Réunion Island, computed for 5 June 2011, and a total column of $1.07 \times 10^{15}$ molecules $\mathrm{cm}^{-2}$. The top panel shows the individual contributions of the main species in the first spectral window. The bottom panel shows the second spectral window.

to $2 \mathrm{~km}$ for the higher layers. For the line spectroscopy we use the HITRAN 2012 database (Rothman et al., 2013) in combination with a number of corrections for $\mathrm{CO}_{2}$ (ATMOS, Brown et al., 1996) (except for Jungfraujoch for which the HITRAN lines are used) and sets of pseudo-lines generated by G. C. Toon (NASA-JPL) to account for broad unresolved absorptions by heavy molecules (e.g. CFC-12, SF6).

Figure 3 shows an example of the fit in both microwindows for the same measured spectra as used in Fig. 1. The top two and bottom two panels show the calculated (green line) and measured spectrum (blue line) and the residual of both micro-windows. The simultaneous fits are good with a standard deviation of $0.15 \%$ in both cases.

\section{Results of the FTIR retrievals}

\subsection{Characteristics of the $\mathrm{NH}_{3}$ retrievals}

\subsubsection{Vertical information}

The retrieved vertical information differs from station to station. The top of Fig. 4 shows the average $\mathrm{NH}_{3}$ volume mixing ratios (VMR) for each of the retrieved layers (blue line) and the a priori profile that was used as input in the retrieval (green line), for the four stations. The bottom of Fig. 4 shows the averaging kernels for each of the four stations averaged over all available observations. As mentioned earlier most of the $\mathrm{NH}_{3}$ at Bremen is in the lowest layers. In Fig. 4 this is also observed as the averaging kernel shows the most sensitivity in the lowest layers (red and green lines for the layers $0.03-0.5$ and $0.5-1 \mathrm{~km}$ ). The combination of the two spectral micro-windows contains, on average, 1.9 degrees of freedom of signal (DOFS) for the Bremen spectra, which means around two independent vertical layers can be retrieved. The two separate layers consist of a layer covering ground $-1 \mathrm{~km}$ and one that covers $1-6 \mathrm{~km}$ height, which can be observed in Fig. 4. It must be taken into account, however, that the averaging kernels shown are a mean of all observations and thus the retrievable number of layers and combined layer depths vary from spectra to spectra. On average, the Lauder spectra have a DOFS of 1.4. There is only vertical information for multiple layers during periods with increased $\mathrm{NH}_{3}$ total columns, which mostly occur during summer. Similar to Bremen, averaging kernels peak near the surface. At Réunion Island, only a DOFS of 1.0 is achieved, with almost no vertical information available. All the averaging kernels peak at the same altitude (about $5 \mathrm{~km}$ ), which is also the peak of the a priori profile (Fig. 4). Similar to the Réunion spectra, the Jungfraujoch spectra do not have vertical information with a DOFS of 1.0.

\subsubsection{Uncertainties budget}

For the error analysis the posteriori error calculation included in the SFIT4 package is used. The error calculation is based on the error estimation approach by Rodgers (2000). It allows the calculation of the error by attributing errors to each of the parameters used in the retrieval. The error budget can be divided into three contributions: the error due to the forward model parameters, the measurement noise and the error due to the vertical resolution of the retrieval (smoothing error). The assumed uncertainties for the parameters used in the retrieval are listed in Table 3 for the parameters used in the calculation for Bremen, Lauder and Réunion. For Jungfraujoch, the error computation was performed using the perturbation method, the spectra of 2009 to 2011 and the Rodger formalism as explained e.g. in Franco et al. (2015). For Réunion Island, the covariance matrix used for the smoothing error has diagonal elements representing $150 \%$ variability from the a 

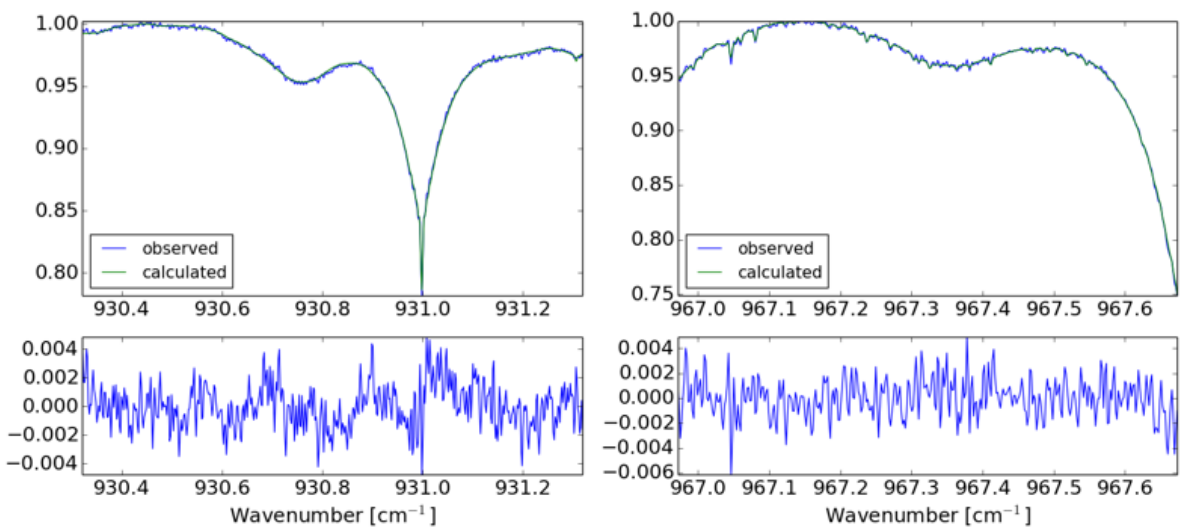

Figure 3. Measured and calculated spectrum for both spectral windows measured with the $125 \mathrm{HR}$ in Bremen on the 19 April 2010 at 09:59 UTC, corresponding to a total column of $18.83 \times 10^{15}$ molecules $\mathrm{NH}_{3} \mathrm{~cm}^{-2}$. The top two panels show the observed (blue line) and calculated (green line) spectra for MW1 (left) and MW2 (right). The bottom two figures show the residuals of the fits in both spectral windows.
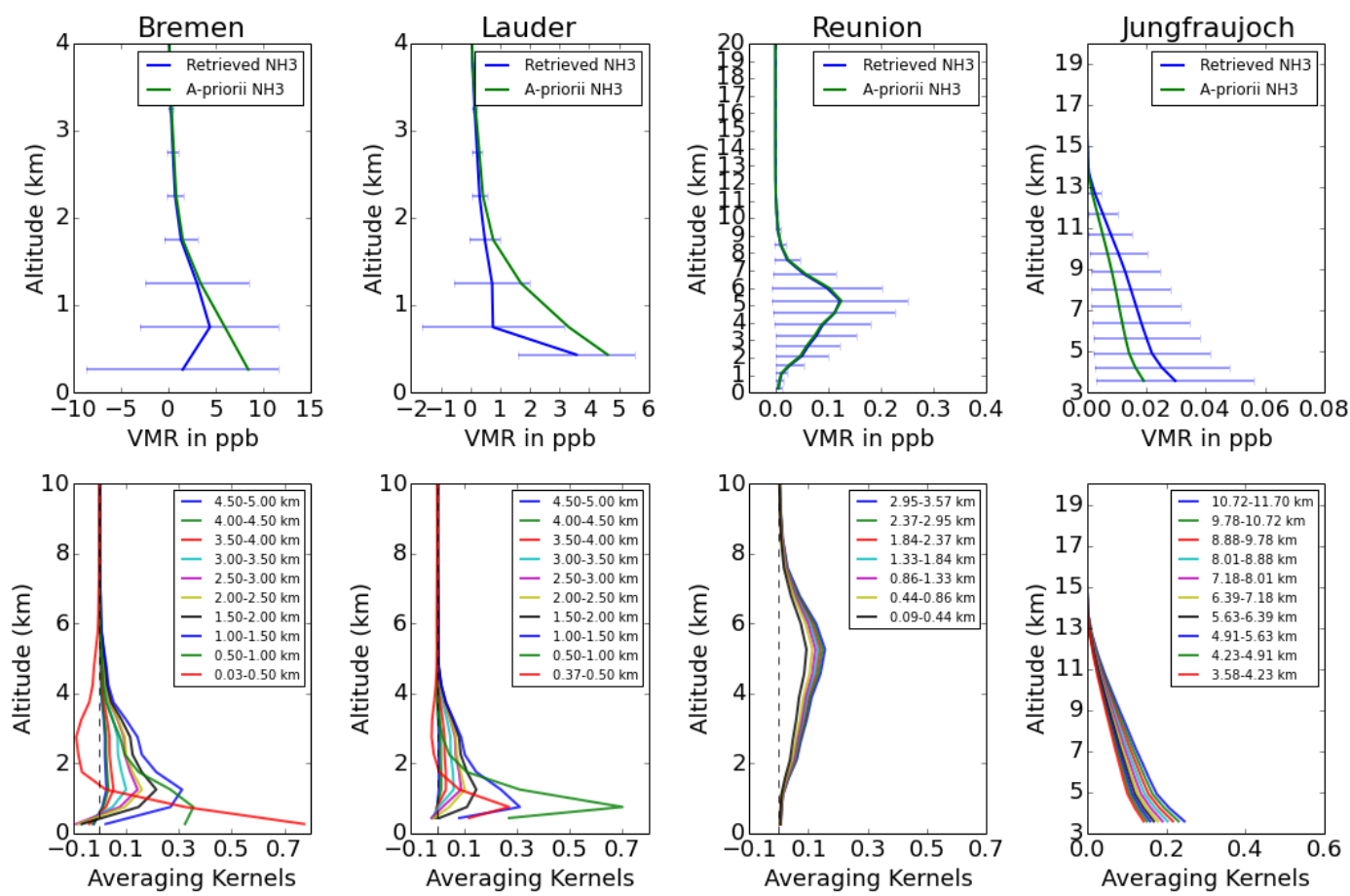

Figure 4. Top panels: the retrieved $\mathrm{NH}_{3}$ profile (blue) and the a priori profile (green) in order from left to right: Bremen (left), Lauder (Left middle), Réunion Island (right middle) and Jungfraujoch (right). Horizontal lines indicate the standard deviation in all observations for each layer. Bottom panels: the normalized averaging kernel for each of the stations.

priori profile. To reflect the error in the NCEP temperature profiles, we assume an uncertainty of about $2 \mathrm{~K}$ in the troposphere and a $5 \mathrm{~K}$ uncertainty in the stratosphere. For the uncertainty in the $\mathrm{NH}_{3}$ line parameters we assume values as stated in the HITRAN 2012 database. We assume a conservative $20 \%$ uncertainty for the intensity and $10 \%$ for both the temperature and pressure broadening coefficients.

The results of the error calculation are listed in Table 4. Combining the systematic and random errors, we have a mean total error of $25.8 \%$ for all the spectra measured at Bremen $(N=554), 30.2 \%$ for the spectra at Lauder $(N=$ $2412), 25.2 \%$ for the Réunion spectra $(N=1262)$ and 34.2 for the Jungfraujoch spectra $(N=2702)$. The errors are dominated by uncertainties in the spectroscopy. In detail, the random error sources amount to a mean error of $9.1 \%$ for the Bremen spectra, which is mostly due to uncertainty in temperature, measurement noise and the zero level of the sensor (i.e. an instrument property). In the case of the systematic 
Table 3. Random and systematic uncertainties used in the error calculation.

\begin{tabular}{|c|c|c|c|c|c|}
\hline \multirow{2}{*}{$\begin{array}{l}\text { Version (stations) } \\
\text { Parameter }\end{array}$} & \multicolumn{2}{|c|}{ SFIT 4 (Bremen, Lauder, Réunion) } & \multirow{2}{*}{$\begin{array}{l}\text { Version (stations) } \\
\text { Parameter }\end{array}$} & \multicolumn{2}{|c|}{ SFIT 2 (Jungfraujoch) } \\
\hline & Random uncertainty & Systematic uncertainty & & Random uncertainty & Systematic uncertainty \\
\hline Temperature & $\begin{array}{l}2 \mathrm{~K} \text { troposphere } \\
5 \mathrm{~K} \text { stratosphere }\end{array}$ & $\begin{array}{l}2 \mathrm{~K} \text { troposphere } \\
5 \mathrm{~K} \text { stratosphere }\end{array}$ & Temperature & $\begin{array}{l}1.5 \mathrm{~K} 0-20 \mathrm{~km} \\
2.0 \mathrm{~K} 20-30 \mathrm{~km} \\
5.0 \mathrm{~K} 30 \mathrm{~km}-\end{array}$ & \\
\hline Solar line shift & $0.005 \mathrm{~cm}^{-1}$ & $0.005 \mathrm{~cm}^{-1}$ & Line intensity & & $20.0 \%$ \\
\hline Solar line strength & $0.1 \%$ & $0.1 \%$ & Line $\mathrm{T}$ broadening & & $10.0 \%$ \\
\hline Solar zenith angle & $0.01^{\circ}$ & $0.01^{\circ}$ & Line $\mathrm{P}$ broadening & & $10.0 \%$ \\
\hline Phase & 0.001 radian (rad) & $0.001 \mathrm{rad}$ & Interfering species & & HITRAN2012: varies \\
\hline Zero level & 0.01 & 0.01 & Instrumental line shape (ILS) & & $10 \%$ \\
\hline Background curvature & & $0.001 \mathrm{~cm}^{-2}$ & Influence of a priori profiles & Calculated & \\
\hline Field of view & & 0.001 & Solar zenith angle (SZA) & $0.2^{\circ}$ & \\
\hline Line intensity & & $20.0 \%$ & & & \\
\hline Line $\mathrm{T}$ broadening & & $10.0 \%$ & & & \\
\hline Line $\mathrm{P}$ broadening & & $10.0 \%$ & & & \\
\hline Interfering species & HITRAN2012: varies & & & & \\
\hline
\end{tabular}

Table 4. Mean random and systematic errors for each of the individual $\mathrm{NH}_{3}$ retrieval parameters. The table is split into two sections to cover both the error calculation using SFIT4 (Bremen, Lauder, Réunion) and SFIT2 (Jungfraujoch). At the bottom the errors are summarized into total mean errors for each of the stations.

\begin{tabular}{|c|c|c|c|c|c|c|c|c|c|}
\hline \multirow{2}{*}{$\begin{array}{l}\text { Station } \\
\text { Parameter }\end{array}$} & \multicolumn{2}{|c|}{ Bremen } & \multicolumn{2}{|c|}{ Lauder } & \multicolumn{2}{|c|}{ Réunion } & \multicolumn{3}{|c|}{ Jungfraujoch } \\
\hline & $\begin{array}{r}\text { Mean } \\
\text { random } \\
\text { error }(\%)\end{array}$ & $\begin{array}{r}\text { Mean } \\
\text { systematic } \\
\text { error }(\%)\end{array}$ & $\begin{array}{r}\text { Mean } \\
\text { random } \\
\text { error }(\%)\end{array}$ & $\begin{array}{r}\text { Mean } \\
\text { systematic } \\
\text { error }(\%)\end{array}$ & $\begin{array}{r}\text { Mean } \\
\text { random } \\
\text { error }(\%)\end{array}$ & $\begin{array}{r}\text { Mean } \\
\text { systematic } \\
\text { error }(\%)\end{array}$ & Parameter & $\begin{array}{r}\text { Mean } \\
\text { random } \\
\text { error }(\%)\end{array}$ & $\begin{array}{r}\text { Mean } \\
\text { systematic } \\
\text { error }(\%)\end{array}$ \\
\hline Temperature & 4.9 & 4.9 & 3.6 & 3.6 & 2.7 & 2.9 & Temperature & 15.2 & \\
\hline Solar zenith angle & 1.6 & 1.6 & & & & & Solar zenith angle & 1.9 & \\
\hline Phase & 1.0 & 1.0 & 1.1 & 1.1 & & & Instrumental line shape & & 1.4 \\
\hline Zero level & 5.0 & 5.0 & 6.8 & 6.8 & & & & & \\
\hline Measurement noise & 4.5 & & 8.4 & & 10.9 & & Measurement noise & 18.2 & \\
\hline Interfering species & 1.3 & & 2.4 & & 0.9 & $\begin{array}{r}8.7\left(\mathrm{H}_{2} \mathrm{O}\right. \\
\text { line pressure } \\
\text { broadening })\end{array}$ & Interfering species & & 1.4 \\
\hline Retrieval parameters & 0.1 & & 0.1 & & & & Model parameters & 1.4 & \\
\hline Background curvature & & 1.1 & & 1.2 & & 0.3 & Forward model & & 1.0 \\
\hline Smoothing error & & 2.8 & & 8.1 & 10.3 & & Smoothing & 5.4 & \\
\hline Spectroscopy & & 21.0 & & 22.7 & & 17.8 & $\begin{array}{l}\text { Spectroscopy } \\
\mathrm{NH}_{3} \text { a priori } \\
\text { Influence of a priori } \\
\text { profiles }\left(\mathrm{H}_{2} \mathrm{O} \& \mathrm{HDO}\right)\end{array}$ & 6.6 & $\begin{array}{r}20.1 \\
6.1\end{array}$ \\
\hline Subtotal error & 9.1 & 23.5 & 12.0 & 27.0 & 15.3 & 20.0 & Subtotal error & 25.3 & 23.1 \\
\hline Total error & & 5.8 & & .2 & & 5.2 & Total & & 1.2 \\
\hline
\end{tabular}

error, with a mean error of $23.5 \%$, the error is for the largest part due to the spectroscopy (i.e. line parameters), with smaller contributions of the temperature, zero level, phase and the smoothing error. The results are similar for the Lauder, Réunion and Jungfraujoch spectra, with most of the uncertainty coming from the line parameters. Hence, line intensity parameters of the ammonia absorption lines are critical for the $\mathrm{NH}_{3}$ concentrations.

\subsection{Time series}

Figure 5 shows the $\mathrm{NH}_{3}$ total columns retrieved from all available spectra from 2004 to 2013 . Table 5 gives a summary of statistics of the retrieved $\mathrm{NH}_{3}$ columns. Individual measurements at Bremen (blue) show high concentrations, especially in spring, with an overall mean column total of $13.7 \times 10^{15}$ molecules $\mathrm{NH}_{3} \mathrm{~cm}^{-2}$ and a root-meansquare error (RMSE) of 20.22 indicating a large variability in the observations. The amplitude of the spring peaks varies 
Table 5. Statistics of the $\mathrm{NH}_{3}$ columns. (No.: number of data points, DOFS: degrees of freedom of signal, mean \pm the error of the mean, RMSE: root-mean-square error.). Total columns are given in $1 \times 10^{15}$ molecules $\mathrm{NH}_{3} \mathrm{~cm}^{-2}$.

\begin{tabular}{lccccc} 
Station & No. & $\begin{array}{c}\text { Mean } \\
\text { DOFS }\end{array}$ & $\begin{array}{c}\text { Mean } \\
\left(\text { molecule } \times 1 \times 10^{15}\right)\end{array}$ & $\begin{array}{c}\text { Median } \\
\left(\text { molecules } \times 1 \times 10^{15}\right)\end{array}$ & $\begin{array}{c}\text { RMSE } \\
\left(\text { molecules } \times 1 \times 10^{15}\right)\end{array}$ \\
\hline Bremen & 554 & 1.9 & $13.75 \pm 4.24$ & 9.51 & 20.22 \\
Lauder & 2412 & 1.4 & $4.17 \pm 1.40$ & 2.85 & 5.95 \\
Réunion & 1262 & 1.0 & $0.80 \pm 0.54$ & 0.56 & 1.14 \\
Jungfraujoch & 2702 & 1.0 & $0.18 \pm 0.07$ & 0.15 & 0.22 \\
\hline
\end{tabular}
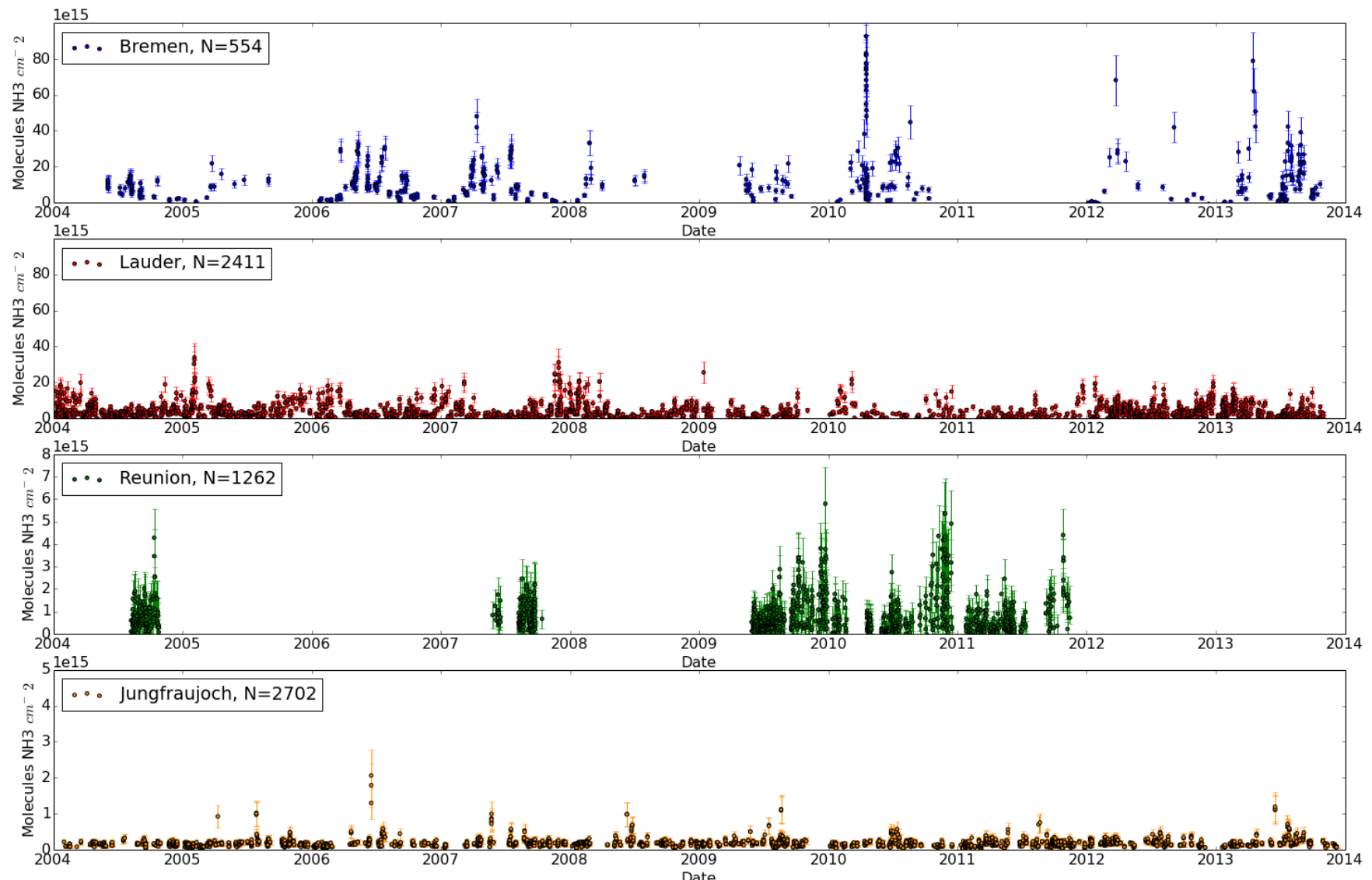

Figure 5. Time series of retrieved $\mathrm{NH}_{3}$ columns (in molecules $\mathrm{NH}_{3} \mathrm{~cm}^{-2}$ ). From top to bottom the figure shows the Bremen (blue), Lauder (red), Réunion (green) and Jungfraujoch (yellow) total columns. The bars reflect the errors in the individual observations.

throughout the years, with maxima in 2010 and 2013, reaching $\sim 93 \times 10^{15}$ and $85 \times 10^{15}$ molecules $\mathrm{NH}_{3} \mathrm{~cm}^{-2}$. The variability through the years is caused by changes in meteorology, emissions and timing of the measurements. Gaps in the data are due to days with overcast and instrument downtimes. The individual observed columns are sorted into monthly averages to analyse the seasonal variability and to understand the processes driving the $\mathrm{NH}_{3}$ concentrations. This is shown in Fig. 6, together with monthly averages of surface temperature and $\mathrm{CO}$ total columns. $\mathrm{NH}_{3}$ column total concentrations at Bremen (Blue line) have a seasonal cycle with highest levels during spring, the summer months and autumn. The maximum concentrations occur around April, which is consistent with temporal emission patterns for manure application reported for this region (Friedrich and Reis, 2004; Van Damme et al., 2015b; Paulot et al., 2014). The baseline variability with higher concentrations in summer can be explained by an increase in volatilization rates of $\mathrm{NH}_{3}$, emitted from livestock housing, which is driven by animal activity and temperature (Gyldenkærne et al., 2005). A comparison is made with $\mathrm{CO}$ to distinguish between agricultural and fire emissions sources. A correlation between $\mathrm{NH}_{3}$ and $\mathrm{CO}$ columns is not observed, which is consistent with agriculture being the dominant source of ammonia. 

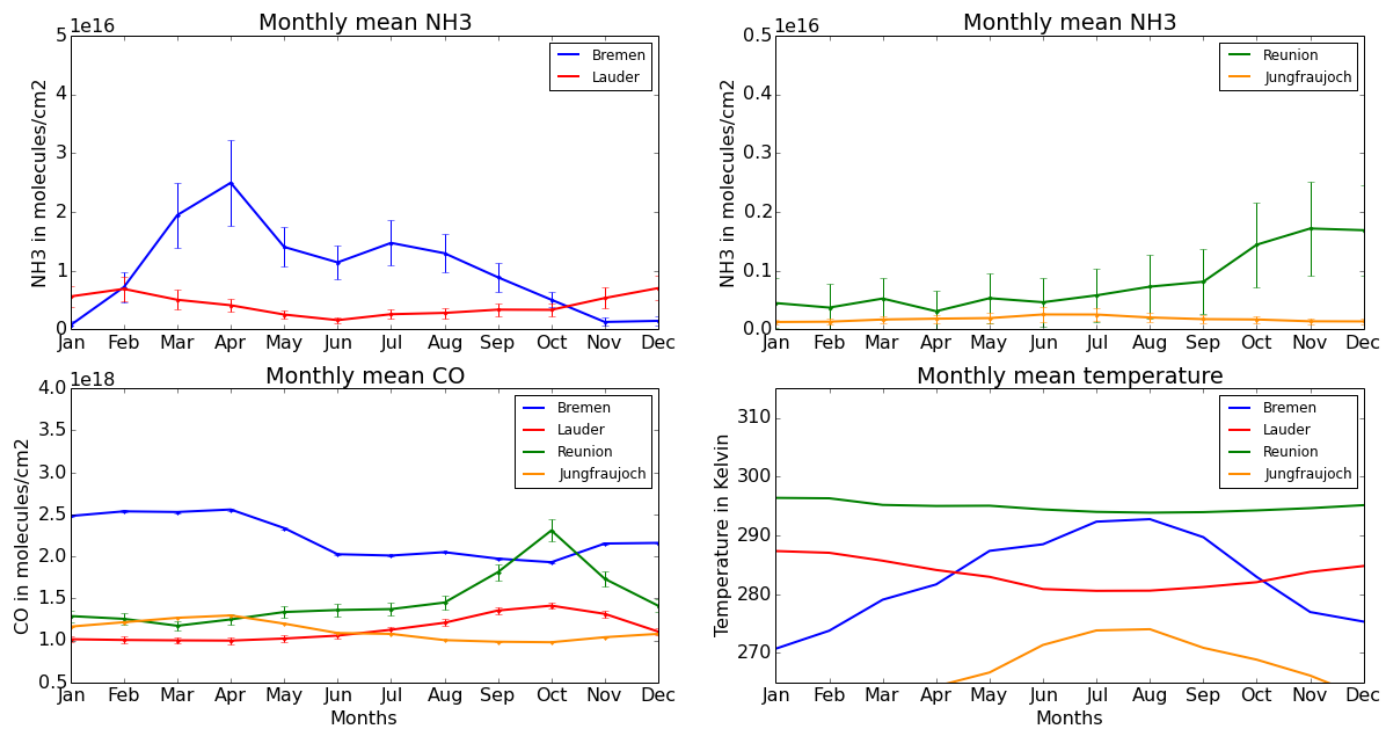

Figure 6. 2004-2013 monthly averaged columns for $\mathrm{NH}_{3}$, $\mathrm{CO}$ and temperature. The top two panels show the monthly $\mathrm{NH}_{3}$ column concentrations (molecules $\mathrm{NH}_{3} \mathrm{~cm}^{-2}$ ) for each of the four stations. Vertical lines indicate the mean monthly error. The bottom two panels show additional column concentrations of $\mathrm{CO}$ (bottom, left) and temperature (bottom, right).

On average the measurements at Lauder (Fig. 5, red line, top panel) yield a column total of $4.17 \times 10^{15}$ molecules $\mathrm{NH}_{3} \mathrm{~cm}^{-2}$. These levels are about one-third of the concentrations measured at Bremen (blue, top panel). Spectra from Lauder are available for most days in the retrieved time series, which makes it easier to discern peaks and variability. Distinctive peaks are only visible in each summer. Maxima during springtimes are not often observed. The peak values are similar in between years, with maxima typically around $30 \times 10^{15}$ molecules $\mathrm{NH}_{3} \mathrm{~cm}^{-2}$. The RMSE of 5.95 reflects a large variability in the observations between individual retrievals. The average error is $1.34 \times 10^{15}$ molecules $\mathrm{NH}_{3}$ $\mathrm{cm}^{-2}$, which is around a quarter of the mean. Figure 6 shows the seasonal cycle of Lauder (red line, top left panel). The seasonal variation of $\mathrm{NH}_{3}$ coincides with that of the atmospheric temperature (red line, bottom right panel) and with the livestock emissions in the surrounding region, which are strongly correlated with temperature.

The third panel of Fig. 5 shows the observations from Réunion (green symbols, bottom panel). The mean column total observed at Réunion is $0.80 \times 10^{15}$ molecules $\mathrm{NH}_{3} \mathrm{~cm}^{-2}$. The concentrations are low during most of the year. However, peaks reaching densities of $\sim 6 \times 10^{15}$ molecules $\mathrm{NH}_{3}$ $\mathrm{cm}^{-2}$ can be observed during the end of each year. The peaks in September-November coincide with the dry season, indicating that emissions are mostly due to biomass burning and large fire events (Vigouroux et al., 2012). This is supported by the increased $\mathrm{CO}$ concentrations, which are also observed in October and November (see, bottom left panel, Fig. 6). $\mathrm{NH}_{3}$ surface concentration measurements are not available for this region but a recent paper by Van Damme et al. (2015b), which uses IASI-NH 3 observations, shows similar seasonal cycles for the south-eastern parts of Africa (Madagascar). Temperature is almost constant throughout the year and is not a major factor in the seasonality of Réunion.

Observations from Jungfraujoch have the lowest mean concentration of all four stations (Fig. 5, orange line), with a mean of $0.18 \times 10^{15}$ molecules $\mathrm{NH}_{3} \mathrm{~cm}^{-2}$. The low concentrations at Jungfraujoch are expected, as the station is located in the free troposphere high above the surrounding valleys. Transport of $\mathrm{NH}_{3}$ from the valleys only occurs sporadically during days with intense vertical mixing. This was also observed in an earlier study of CO concentrations (Barret et al., 2003). The Jungfraujoch observations show almost no seasonal effects with only a minimal increase during the summer months. The low concentrations measured at Jungfraujoch support our assumption on the vertical distribution of the ammonia concentrations with low values in the troposphere that were used in our a priori profiles.

\section{Conclusions and perspectives}

In this study we presented a new method to retrieve ammonia total columns from ground-based FTIR solar spectra. Observations from four complementary stations were used to illustrate the capabilities of the retrieval method. $\mathrm{NH}_{3}$ total columns ranging 3 orders of magnitude were obtained with high abundances at Bremen (mean of $13.7 \times 10^{15}$ molecules $\mathrm{cm}^{-2}$, with a mean DOFS of 1.9) to low columns at Jungfraujoch (mean of $0.18 \times 10^{15}$ molecules $\mathrm{cm}^{-2}$, with a mean DOFS of 1.0). The very low levels obtained at Jungfraujoch demonstrate the sensitivity of the retrieval method we 
developed. A separate error calculation shows random errors in the order of $10 \%$ and systematic errors of $25 \%$ for individual observations. The errors are dominated by uncertainties in spectroscopy, atmospheric temperature and deviations in instrumental parameters. For conditions with high surface concentrations of ammonia, as in Bremen, it is possible to retrieve information on the vertical gradient as two layers can be discriminated. At Bremen, the retrieval is most sensitive to ammonia in the planetary boundary layer, where most of the ammonia is expected. For conditions with lower concentrations there is not enough information to discriminate individual layers. Station-specific seasonal cycles were found to be consistent with known seasonal cycles of the dominant ammonia sources in the station surroundings. For example, highest levels in Bremen were observed during springtime when manure is applied to the fields, with column total concentrations reaching up to $93 \times 10^{15}$ molecules $\mathrm{cm}^{-2}$.

Remote sensing techniques avoid sampling artefacts common to other techniques such as filter packs (Puchalski et al., 2011; von Bobrutzki et al., 2010). For in situ observations, open-path remote sensing techniques, e.g. DOAS and QCL instruments, are starting to be used (Volten et al., 2010; Miller et al., 2014). The FTIR-NH 3 observations would be an excellent addition to these approaches as it provides the $\mathrm{NH}_{3}$ total column and profiles, including vertical information, for sites sampling high ammonia levels. With a mean error of $\sim 25 \%$ for all observations in high ammonia source areas, the accuracy of the FTIR retrievals is comparable to that reported for satellite products (TES, IASI, CrIS). Compared to the in situ open-path remote sensing methods, the FTIR method has a higher uncertainty, but this is a tradeoff for the ability to retrieve vertical information. To improve the accuracy of the FTIR- $\mathrm{NH}_{3}$ retrieval, a reassessment of the spectral line parameters is necessary.

Observations from existing networks commonly represent daily or even monthly averaged concentration values, which severely complicates any attempt to validate satellite observations. The novel FTIR-NH 3 observations enable a direct validation of satellite products. As the FTIR- $\mathrm{NH}_{3}$ product provides averaging kernels, a direct comparison can be made with optimal estimation satellite retrievals while taking account of the a priori information and vertical sensitivity of both instruments (Rodgers and Connor, 2003). A dedicated field campaign was executed at the Cabauw Experimental Site for Atmospheric Remote Sensing (CESAR) in the Netherlands (spring and summer 2014) to validate the IASI-NH $\mathrm{N}_{3}$ using a range of instruments, including miniDOAS instruments and a Bruker IFS-66 instrument.

The uncertainty in the emission distributions hampers the performance and prediction capabilities of air quality and climate models (Heald et al., 2012). Emissions are usually based on nationally reported yearly emission inventories (Pouliot et al., 2012) and gridded by distributing the emissions according to animal populations and agricultural land use (Bouwman et al., 2002; Kuenen et al., 2011). To improve on static emission time profiles, a new direction is to include the impact of the meteorological variability of ammonia emissions in modelling systems (Sutton et al., 2013). Recently, such an improvement was shown to greatly enhance the performance of air quality models (Skjøth et al., 2011). Satellite observations in combination with chemical transport models (CTM) have been used to provide a top-down constraint on ammonia emissions (e.g. Zhu et al., 2013). Similar to satellite observations, FTIR total columns in combination with surface and satellite observations could provide the means to evaluate the emission modelling through comparing trends and concentration anomalies within and between years. For this purpose continuous time series are necessary. Due to the lack of continuous data (i.e. more than one observation per hour) we could not derive a typical diurnal cycle in this study, whereas this would be highly useful for model evaluation. Improved knowledge on the diurnal cycles may also greatly help to interpret model evaluation results compared to satellite data, as they provide snapshots, e.g. daily observations by IASI at 09:30 local time. Also, the modelmeasurement comparison would be less sensitive to modelling errors in the turbulent vertical exchange as the ammonia is integrated vertically.

The developed retrieval methodology from FTIR instruments provides a new way of obtaining vertically and temporally resolved measurements of ammonia concentrations. FTIR-NH $\mathrm{NH}_{3}$ observations may prove very valuable for satellite and model validation and may provide a complementary source of information to constrain the global ammonia budget.

Acknowledgements. This work is part of the research programme GO/12-36, which is financed by the Netherlands Organisation for Scientific Research (NWO). Acknowledgements are addressed to the Université de La Réunion and CNRS (LACy-UMR8105 and UMS3365) for their strong support of the OPAR station (Observatoire de Physique de l'Atmosphère de la Réunion) and the OSU-R (Observatoire des Sciences de l'Univers de la Réunion) activities. The authors gratefully acknowledge C. Hermans and F. Scolas from BIRA-IASB, and J.-M. Metzger from Université de La Réunion, for the Réunion Island measurements. We are also grateful to Louisa Emmons (NCAR) who provided $\mathrm{NH}_{3}$ profiles from the MOZART model used as a priori information in the Réunion Island retrievals. The University of Liège contribution to the present work has mainly been supported by the A3C project (PRODEX Program of the Belgian Science Policy Office, BELSPO, Brussels). Additional support was provided by MeteoSwiss (Global Atmospheric Watch), the Fédération Wallonie-Bruxelles and the F.R.S.-FNRS. We thank the International Foundation High Altitude Research Stations Jungfraujoch and Gornergrat (HFSJG, Bern). E. Mahieu is a Research Associate with F.R.S.-FNRS. The Lauder NIWA FTIR program is funded through the New Zealand government's core research grant framework. We are grateful to the many colleagues who have contributed to FTIR data acquisition at the various sites. 
Edited by: F. Dentener

\section{References}

Barret, B., De Mazière, M., and Mahieu, E.: Ground-based FTIR measurements of $\mathrm{CO}$ from the Jungfraujoch: characterisation and comparison with in situ surface and MOPITT data, Atmos. Chem. Phys., 3, 2217-2223, doi:10.5194/acp-3-2217-2003, 2003.

Bobbink, R., Hornung, M., and Roelofs, J. G.: The effects of airborne nitrogen pollutants on species diversity in natural and semi-natural European vegetation, J. Ecol., 86, 717-738, 1998.

Bobbink, R., Hicks K., Galloway J., Spranger T., Alkemade R., Ashmore M., Bustamante M., Cinderby S., Davidson E., Dentener F., Emmett B., Erisman, J. W., Fenn, M., Gilliam, F., Nordin, A., Pardo, L., and De Vries, W.: Global assessment of nitrogen deposition effects on terrestrial plant diversity: a synthesis, Ecol. Appl., 20, 30-59, 2010.

Bouwman, A. F., Lee, D. S., Asman, W. A. H., Dentener, F. J., Van Der Hoek, K. W., and Olivier, J. G. J.: A global high-resolution emission inventory for ammonia, Global Biogeochem. Cycles, 11, 561-587, 1997.

Bouwman, A. F., Boumans, L. J. M., and Batjes, N. H.: Estimation of global NH3 volatilization loss from synthetic fertilizers and animal manure applied to arable lands and grasslands, Global Biogeochem. Cycles, 16, 1024, doi:10.1029/2000GB001389, 2002.

Brown, L. R., Gunson, M. R., Toth, R. A., Irion, F. W., Rinsland, C. P., and Goldman, A.: 1995 atmospheric trace molecule spectroscopy (ATMOS) linelist, Appl. Optics, 35, 2828-2848, 1996.

Chang, L., Palo, S., Hagan, M., Richter, J., Garcia, R., Riggin, D., and Fritts, D.: Structure of the migrating diurnal tide in the Whole Atmosphere Community Climate Model (WACCM), Adv. Space Res., 41, 1398-1407, doi:10.1016/j.asr.2007.03.035, 2008.

Charlson, R. J., Langner, J., Rodhe, H., Leovy, C. B., and Warren, S. G.: Perturbation of the Northern-Hemisphere radiative balance by backscattering from anthropogenic sulfate 15 aerosols, Tellus A, 43, 152-163, 1991.

Clarisse, L., Clerbaux, C., Dentener, F., Hurtmans, D., and Coheur, P.-F.: Global ammonia distribution derived from infrared satellite observations, Nat. Geosci., 2, 479-483, 2009.

Dämmgen, U. and Erisman, J. W.: Emission, transmission, deposition and environmental effects of ammonia from agricultural sources, in: Emissions from European agriculture, edited by: Kuczynski, T., Dämmgen, U., Webb, J., and Myczko, A., Wageningen Academic Publishers, Wageningen, the Netherlands, p. 97-112, 2005.

Dentener, F., Drevet, J., Lamarque, J. F., Bey, I., Eickhout, B., Fiore, A. M., Hauglustaine, D., Horowitz, L. W., Krol, M., Kulshrestha, U. C., Lawrence, M., Galy-Lacaux, C., Rast, S., Shindell, D., Stevenson, D., Van Noije, T., Atherton, C., Bell, N., Bergman, D., Butler, T., Cofala, J., Collins, B., Doherty, R., Ellingsen, K., Galloway, J., Gauss, M., Montanaro, V., Müller, J. F., Pitari, G., Rodriguez, J., Sanderson, M., Solmon, F., Strahan, S., Schultz, M., Sudo, K., Szopa, S., and Wild, O.: Nitrogen and sulfur deposition on regional and global scales: A multimodel evaluation, Global
Biogeochem. Cycles, 20, GB4003, doi:10.1029/2005GB002672, 2006.

Dils, B., De Mazière, M., Müller, J. F., Blumenstock, T., Buchwitz, M., de Beek, R., Demoulin, P., Duchatelet, P., Fast, H., Frankenberg, C., Gloudemans, A., Griffith, D., Jones, N., Kerzenmacher, T., Kramer, I., Mahieu, E., Mellqvist, J., Mittermeier, R. L., Notholt, J., Rinsland, C. P., Schrijver, H., Smale, D., Strandberg,0 A., Straume, A. G., Stremme, W., Strong, K., Sussmann, R., Taylor, J., van den Broek, M., Velazco, V., Wagner, T., Warneke, T., Wiacek, A., and Wood, S.: Comparisons between SCIAMACHY and ground-based FTIR data for total columns of $\mathrm{CO}, \mathrm{CH}_{4}, \mathrm{CO}_{2}$ and $\mathrm{N}_{2} \mathrm{O}$, Atmos. Chem. Phys., 6, 1953-1976, doi:10.5194/acp6-1953-2006, 2006.

EDGAR - Emission Database for Global Atmospheric Research: Source: EC-JRC/PBL. EDGAR version 4.2, http://edgar.jrc.ec. europa.eu (last access: 15 October 2012), 2011.

Erisman, J. W., Otjes, R., Hensen, A., Jongejan, P., van den Bulk, P., Khlystov, A., Mols, H., and Slanina, J.: Instrument development and application in studies and monitoring of ambient ammonia, Atmos. Environ., 35, 1913-1922, 2001.

Erisman, J. W., Bleeker, A., Galloway, J., and Sutton, M. S.: Reduced nitrogen in ecology and the environment, Environ. Pollut., 150, 140-149, 2007.

Erisman, J. W., Bleeker, A., Hensen, A., and Vermeulen, A.: Agricultural air quality in Europe and the future perspectives, Atmos. Environ., 42, 3209-3217, doi:10.1016/j.atmosenv.2007.04.004, 2008.

Fowler, D., Coyle, M., Skiba, U., Sutton, M. A., Cape, J. N., Reis, S., Sheppard, L. J., Jenkins, A., Grizzetti, B., Galloway, J. N., Vitousek, P., Leach, A., Bouwman, A. F., ButterbachBahl, K., Dentener, F., Stevenson, D., Amann, M., and Voss, M.: The global nitrogen cycle in the twenty-first century, Phil. Trans. R. Soc. London B Biol. Sci., 368, published online, available at: http://rstb.royalsocietypublishing.org/content/368/1621/ 20130164.abstract, 2013.

Franco, B., Hendrick, F., Van Roozendael, M., Müller, J.-F., Stavrakou, T., Marais, E. A., Bovy, B., Bader, W., Fayt, C., Hermans, C., Lejeune, B., Pinardi, G., Servais, C., and Mahieu, E.: Retrievals of formaldehyde from ground-based FTIR and MAX-DOAS observations at the Jungfraujoch station and comparisons with GEOS-Chem and IMAGES model simulations, Atmos. Meas. Tech., 8, 1733-1756, doi:10.5194/amt-8-1733-2015, 2015.

Friedrich, R. and Reis, S. (Eds.): Emissions of Air Pollutants Measurements, Calculations and Uncertainties, 3-540-00840-3, Springer-Verlag, Berlin Heidelberg New York, 2004.

Griesfeller, A., Griesfeller, J., Hase, F., Kramer, I., Loës, P., Mikuteit, S., Raffalski, U., Blumenstock, T., and Nakajima, H.: Comparison of ILAS-II and ground-based FTIR measurements of $\mathrm{O}_{3}, \mathrm{HNO}_{3}, \mathrm{~N}_{2} \mathrm{O}$, and $\mathrm{CH}_{4}$ over Kiruna, Sweden, J. Geophys. Res., 111, D11S07, doi:10.1029/2005JD006451, 2006.

Griffith, D. W. T., Jones, N. B., McNamara, B., Walsh, C. P., Bell, W., and Bernardo, C.: Intercomparison of NDSC ground-based solar FTIR measurements of atmospheric gases at Lauder, New Zealand, J. Atmos. Ocean. Tech., 20, 1138-1153, 2003.

Gyldenkærne, S., Skjøth, C. A., Hertel, O., and Ellermann, T.: A dynamical ammonia emission parameterization for use in air pollution models, J. Geophys. Res.-Atmos., 110, 1-14, doi:10.1029/2004JD005459, 2005. 
Hansen, D. A., Edgerton, E. S., Hartsell, B. E., Jansen, J. J., Kandasamy, N., Hidy, G. M., and Blanchard, C. L.: The southeastern aerosol research and characterization study: Part 1. Overview, J. Air Waste Manage. Assoc., 53, 1460-1471, doi:10.1080/10473289.2003.10466318, 2003.

Hase, F., Blumenstock, T., and Paton-Walsh, C.: Analysis of the instrumental line shape of high-resolution fourier transform IR spectrometers with gas cell measurements and new retrieval software, Appl. Optics, 38, 3417-3422, 1999.

Hase, F., Hannigan, J. W., Coffey, M. T., Goldman, A., Höpfner, M., Jones, N. B., Rinsland, C. P., and Wood, S. W.: Intercomparison of retrieval codes used for the analysis of high-resolution, ground-based FTIR measurements, J. Quant. Spectrosc. Ra., 87, 25-52, doi:10.1016/j.jqsrt.2003.12.008, 2004.

Hase, F., Demoulin, P., Sauval, A. J., Toon, G. C., Bernath, P. F., Goldman, A., Hannigan, J. W., and Rinsland, C. P.: An empirical line-by-line model for the infrared solar transmittance spectrum from 700 to $5000 \mathrm{~cm}^{-1}$, J. Quant. Spectrosc. Ra., 102, 450-463, doi:10.1016/j.jqsrt.2006.02.026, 2006.

Heald, C. L., Collett Jr., J. L., Lee, T., Benedict, K. B., Schwandner, F. M., Li, Y., Clarisse, L., Hurtmans, D. R., Van Damme, M., Clerbaux, C., Coheur, P.-F., Philip, S., Martin, R. V., and Pye, H. O. T.: Atmospheric ammonia and particulate inorganic nitrogen over the United States, Atmos. Chem. Phys., 12, 10295-10312, doi:10.5194/acp-12-10295-2012, 2012.

Holland, E. A., Dentener, F. J., Braswell, B. H., and Sulzman, J. M.: Contemporary and pre-industrial global reactive nitrogen budgets, in: New Perspectives on Nitrogen Cycling in the Temperate and Tropical Americas, p. 7-43, Springer, the Netherlands, 1999.

Kerzenmacher, T., Dils, B., Kumps, N., Blumenstock, T., Clerbaux, C., Coheur, P.-F., Demoulin, P., García, O., George, M., Griffith, D. W. T., Hase, F., Hadji-Lazaro, J., Hurtmans, D., Jones, N., Mahieu, E., Notholt, J., Paton-Walsh, C., Raffalski, U., Ridder, T., Schneider, M., Servais, C., and De Mazière, M.: Validation of IASI FORLI carbon monoxide retrievals using FTIR data from NDACC, Atmos. Meas. Tech., 5, 2751-2761, doi:10.5194/amt5-2751-2012, 2012.

Krupa, S.: Effects of atmospheric ammonia (NH3) on terrestrial vegetation: a review, Environ. Pollut., 124, 179-221, doi:10.1016/S0269-7491(02)00434-7, 2003.

Kuenen, J., Denier van der Gon, H., Visschedijk, A., van der Brugh, H., and van Gijlswijk, R.: MACC European emission inventory for the years 2003-2007, TNO Rep. TNO-060-UT-2011-00588, TNO, Utrecht, the Netherlands, 2011.

Leen, J. B., Yu, X. Y., Gupta, M., Baer, D. S., Hubbe, J. M., Kluzek, C. D., Tomlinson, J. M., and Hubbell, M. R.: Fast in situ airborne measurement of ammonia using a mid-infrared off-axis ICOS spectrometer, Environ. Sci. Technol., 47, 10446-10453, doi:10.1021/es401134u, 2013.

Luo, M., Shephard, M. W., Cady-Pereira, K. E., Henze, D. K., Zhu, L., Bash, J. O., Pinder, R. W., Capps, S., and Walker, J.: Satellite Observations of Tropospheric Ammonia and Carbon Monoxide: Global Distributions, Correlations and Comparisons to Model Simulations, Atmos. Environ., 106, 262-277, doi:10.1016/j.atmosenv.2015.02.007, 2015.

Miller, D. J., Sun, K., Tao, L., Khan, M. A., and Zondlo, M. A.: Open-path, quantum cascade-laser-based sensor for highresolution atmospheric ammonia measurements, Atmos. Meas. Tech., 7, 81-93, doi:10.5194/amt-7-81-2014, 2014.
Mount, G. H., Rumburg, B., Havig, J., Lamb, B., Westberg, H., Yonge, D., Johnson, K., and Kincaid, R.: Measurement of atmospheric ammonia at a dairy using differential optical absorption spectroscopy in the mid-ultraviolet, Atmos. Environ., 36, 17991810, 2002.

Nowak, J. B., Neuman, J. A., Kozai, K., Huey, L. G., Tanner, D. J., Holloway, J. S., Ryerson, T. B., Frost, G. J., McKeen, S. A., and Fehsenfeld, F. C.: A chemical ionization mass spectrometry technique for airborne measurements of ammonia, J. Geophys. Res.-Atmos., 112, D10S02, doi:10.1029/2006JD007589, 2007.

Nowak, J. B., Neuman, J. A., Bahreini, R., Brock, C. A., Middlebrook, A. M., Wollny, A. G., Holloway, J. S., Peischl, J., Ryerson, T. B., and Fehsenfeld, F. C.: Airborne observations of ammonia and ammonium nitrate formation over Houston, Texas, J. Geophys. Res.-Atmos., 115, D22304, doi:10.1029/2010JD014195, 2010.

Paton-Walsh, C., Jones, N. B., Wilson, S. R., Haverd, V., Meier, A., Griffith, D. W. T., and Rinsland, C. P.: Measurements of trace gas emissions from Australian forest fires and correlations with coincident measurements of aerosol optical depth, J. Geophys. Res.-Atmos., 110, 1-6, doi:10.1029/2005JD006202, 2005.

Paulot, F., Jacob, D. J., Pinder, R. W., Bash, J. O., Travis, K., and Henze, D. K.: Ammonia emissions in the United States, European Union, and China derived by high resolution inversion of ammonium wet deposition data: Interpretation with a new agricultural emissions inventory (MASAGE NH3), J. Geophys. Res.Atmos., 119, 4343-4364, doi:10.1002/2013JD021130, 2014.

Pope III, C. A., Ezzati, M., and Dockery, D. W.: Fine-Particulate Air Pollution and Life Expectancy in the United States, N. Engl. J. Med., 360, 376-386, doi:10.1056/NEJMsa0805646, 2009.

Pougatchev, N. S., Connor, B. J., and Rinsland, C. P.: Infrared measurements of the ozone vertical distribution above Kitt Peak, J. Geophys. Res.-Atmos., 100, 16689-16697, 1995.

Pouliot, G., Pierce, T., van der Gon, H. D., Schaap, M., Moran, M., and Nopmongcol, U.: Comparing emission inventories and model-ready emission datasets between Europe and North America for the AQMEII project, Atmos. Environ., 53, 4-14, doi:10.1016/j.atmosenv.2011.12.041, 2012.

Puchalski, M. A., Sather, M. E., Walker, J. T., Lehmann, C. M., Gay, D. A., Mathew, J., and Robarge, W. P.: Passive ammonia monitoring in the United States: Comparing three different sampling devices, J. Environ. Monit., 13, 3156-3167, doi:10.1039/c1em10553a, 2011.

Rao, K. N. and Weber, A.: Spectroscopy qf the Earth's Atmosphere and Interstellar Medium, Academic, San Diego, Calif., 1992.

Reay, D. S., Dentener, F., Smith, P., Grace, J., and Feely, R. A.: Global nitrogen deposition and carbon sinks, Nat. Geosci., 1, 430-437, 2008.

Rodgers, C. D.: Inverse Methods for Atmospheric Sounding - Theory and Practice, 2, 256, doi:10.1142/9789812813718, 2000.

Rodgers, C. D. and Connor, B. J.: Intercomparison of remote sounding instruments, J. Geophys. Res.-Atmos., 108, published online, doi:10.1029/2002JD002299, 2003.

Rodhe, H., Dentener, F., and Schulz, M.: The global distribution of acidifying wet deposition, Environ. Sci. Technol., 36, 43824388, 2002.

Rothman, L. S., Gordon, I. E., Babikov, Y., Barbe, A., Chris Benner, D., Bernath, P. F., Birk, M., Bizzocchi, L., Boudon, V., Brown, L. R., Campargue, A., Chance, K., Cohen, E. A., Coudert, L. H., 
Devi, V. M., Drouin, B. J., Fayt, A., Flaud, J. M., Gamache, R. R., Harrison, J. J., Hartmann, J. M., Hill, C., Hodges, J. T., Jacquemart, D., Jolly, A., Lamouroux, J., Le Roy, R. J., Li, G., Long, D. a., Lyulin, O. M., Mackie, C. J., Massie, S. T., Mikhailenko, S., Müller, H. S. P., Naumenko, O. V., Nikitin, A. V., Orphal, J., Perevalov, V., Perrin, A., Polovtseva, E. R., Richard, C., Smith, M. A. H., Starikova, E., Sung, K., Tashkun, S., Tennyson, J., Toon, G. C., Tyuterev, V. G., and Wagner, G.: The HITRAN2012 molecular spectroscopic database, J. Quant. Spectrosc. Ra., 130, 4-50, doi:10.1016/j.jqsrt.2013.07.002, 2013.

Schaap, M., van Loon, M., ten Brink, H. M., Dentener, F. J., and Builtjes, P. J. H.: Secondary inorganic aerosol simulations for Europe with special attention to nitrate, Atmos. Chem. Phys., 4, 857-874, doi:10.5194/acp-4-857-2004, 2004.

Senten, C., De Mazière, M., Dils, B., Hermans, C., Kruglanski, M., Neefs, E., Scolas, F., Vandaele, A. C., Vanhaelewyn, G., Vigouroux, C., Carleer, M., Coheur, P. F., Fally, S., Barret, B., Baray, J. L., Delmas, R., Leveau, J., Metzger, J. M., Mahieu, E., Boone, C., Walker, K. A., Bernath, P. F., and Strong, K.: Technical Note: New ground-based FTIR measurements at Ile de La Réunion: observations, error analysis, and comparisons with independent data, Atmos. Chem. Phys., 8, 3483-3508, doi:10.5194/acp-8-3483-2008, 2008.

Shephard, M. W. and Cady-Pereira, K. E.: Cross-track Infrared Sounder (CrIS) satellite observations of tropospheric ammonia, Atmos. Meas. Tech., 8, 1323-1336, doi:10.5194/amt-8-13232015, 2015.

Shephard, M. W., Cady-Pereira, K. E., Luo, M., Henze, D. K., Pinder, R. W., Walker, J. T., Rinsland, C. P., Bash, J. O., Zhu, L., Payne, V. H., and Clarisse, L.: TES ammonia retrieval strategy and global observations of the spatial and seasonal variability of ammonia, Atmos. Chem. Phys., 11, 10743-10763, doi:10.5194/acp-11-10743-2011, 2011.

Shephard, M. W., McLinden, C. A., Cady-Pereira, K. E., Luo, M., Moussa, S. G., Leithead, A., Liggio, J., Staebler, R. M., Akingunola, A., Makar, P., Lehr, P., Zhang, J., Henze, D. K., Millet, D. B., Bash, J. O., Zhu, L., Wells, K. C., Capps, S. L., Chaliyakunnel, S., Gordon, M., Hayden, K., Brook, J. R., Wolde, M., and Li, S.-M.: Tropospheric Emission Spectrometer (TES) satellite validations of ammonia, methanol, formic acid, and carbon monoxide over the Canadian oil sands, Atmos. Meas. Tech. Discuss., 8, 9503-9563, doi:10.5194/amtd-8-9503-2015, 2015.

Skjøth, C. A., Geels, C., Berge, H., Gyldenkærne, S., Fagerli, H., Ellermann, T., Frohn, L. M., Christensen, J., Hansen, K. M., Hansen, K., and Hertel, O.: Spatial and temporal variations in ammonia emissions - a freely accessible model code for Europe, Atmos. Chem. Phys., 11, 5221-5236, doi:10.5194/acp-11-52212011, 2011.

Sussmann, R., Borsdorff, T., Rettinger, M., Camy-Peyret, C., Demoulin, P., Duchatelet, P., Mahieu, E., and Servais, C.: Technical Note: Harmonized retrieval of column-integrated atmospheric water vapor from the FTIR network - first examples for longterm records and station trends, Atmos. Chem. Phys., 9, 89878999, doi:10.5194/acp-9-8987-2009, 2009.

Sutton, M. A., Reis, S., Riddick, S. N., Dragosits, U., Nemitz, E., Theobald, M. R., Tang, Y. S., Braban, C. F., Vieno, M., Dore, A. J., Mitchell, R. F., Wanless, S., Daunt, F., Fowler, D., Blackall, T. D., Milford, C., Flechard, C. R., Loubet, B., Massad, R., Cellier, P., Personne, E., Coheur, P. F., Clarisse,
L., Van Damme, M., Ngadi, Y., Clerbaux, C., Skjøth, C. A., Geels, C., Hertel, O., Wichink Kruit, R. J., Pinder, R. W., Bash, J. O., Walker, J. T., Simpson, D., Horváth, L., Misselbrook, T. H., Bleeker, A., Dentener, F., and de Vries, W.: Towards a climate-dependent paradigm of ammonia emission and deposition, Philos. Trans. R. Soc. London, Ser. B, 368, 20130166 , doi:10.1098/rstb.2013.0166, 2013.

Thijsse, T. R., Duyzer, J. H., Verhagen, H. L. M., Wyers, G. P., Wayers, A., and Möls, J. J.: Measurement of ambient ammonia with diffusion tube samplers, Atmos. Environ., 32, 333-337, 1998.

Thomas, R. M., Trebs, I., Otjes, R., Jongejan, P. A. C., ten Brink, H., Phillips, G., Kortner, M., Meixner, F. X., and Nemitz, E.: An automated analyzer to measure surface-atmosphere exchange fluxes of water soluble inorganic aerosol compounds and reactive trace gases, Environ. Sci. Technol., 43, 1412-1418, 2009.

Toon, G. C., Blavier, J.-F., Sen, B., Margitan, J. J., Webster, C. R., Max, R. D., Fahey, D. W., Gao, R., DelNegro, L., Proffitt, M., Elkins, J., Romashkin, P. A., Hurst, D. F., Oltmans, S., Atlas, E., Schauffler, S., Flocke, F., Bui, T. P., Stimpfle, R. M., Bonne, G. P., Voss, P. B., and Cohen, R. C.: Comparison of MkIV balloon and ER-2 aircraft measurements of atmospheric trace gases, J. Geophys. Res., 104, 26779-26790, 1999.

Van Damme, M., Clarisse, L., Heald, C. L., Hurtmans, D., Ngadi, Y., Clerbaux, C., Dolman, A. J., Erisman, J. W., and Coheur, P. F.: Global distributions, time series and error characterization of atmospheric ammonia $\left(\mathrm{NH}_{3}\right)$ from IASI satellite observations, Atmos. Chem. Phys., 14, 2905-2922, doi:10.5194/acp-14-29052014, 2014a.

Van Damme, M., Wichink Kruit, R. J., Schaap, M., Clarisse, L., Clerbaux, C., Coheur, P.-F., Dammers, E., Dolman, A. J., and Erisman, J. W.: Evaluating 4 years of atmospheric ammonia $\left(\mathrm{NH}_{3}\right)$ over Europe using IASI satellite observations and LOTOS-EUROS model results, J. Geophys. Res.Atmos., 119, 9549-9566, doi:10.1002/2014JD021911, 2014b.

Van Damme, M., Clarisse, L., Dammers, E., Liu, X., Nowak, J. B., Clerbaux, C., Flechard, C. R., Galy-Lacaux, C., Xu, W., Neuman, J. A., Tang, Y. S., Sutton, M. A., Erisman, J. W., and Coheur, P. F.: Towards validation of ammonia $\left(\mathrm{NH}_{3}\right)$ measurements from the IASI satellite, Atmos. Meas. Tech., 8, 15751591, doi:10.5194/amt-8-1575-2015, 2015a.

Van Damme, M., Erisman, J. W., Clarisse, L., Dammers, E., Whitburn, S., Clerbaux, C., Dolman, A. J., and Coheur, P.-F.: Worldwide spatiotemporal atmospheric ammonia $\left(\mathrm{NH}_{3}\right)$ columns variability revealed by satellite, Geophys. Res. Lett., 42, 8660-8668, doi:10.1002/2015GL065496, 2015 b.

Vigouroux, C., Hendrick, F., Stavrakou, T., Dils, B., De Smedt, I., Hermans, C., Merlaud, A., Scolas, F., Senten, C., Vanhaelewyn, G., Fally, S., Carleer, M., Metzger, J.-M., Müller, J.-F., Van Roozendael, M., and De Mazière, M.: Ground-based FTIR and MAX-DOAS observations of formaldehyde at Réunion Island and comparisons with satellite and model data, Atmos. Chem. Phys., 9, 9523-9544, doi:10.5194/acp-9-9523-2009, 2009.

Vigouroux, C., Stavrakou, T., Whaley, C., Dils, B., Duflot, V., Hermans, C., Kumps, N., Metzger, J.-M., Scolas, F., Vanhaelewyn, G., Müller, J.-F., Jones, D. B. A., Li, Q., and De Mazière, M.: FTIR time-series of biomass burning products $\left(\mathrm{HCN}, \mathrm{C}_{2} \mathrm{H}_{6}\right.$, $\mathrm{C}_{2} \mathrm{H}_{2}, \mathrm{CH}_{3} \mathrm{OH}$, and $\left.\mathrm{HCOOH}\right)$ at Reunion Island $\left(21^{\circ} \mathrm{S}, 55^{\circ} \mathrm{E}\right)$ and comparisons with model data, Atmos. Chem. Phys., 12, 10367-10385, doi:10.5194/acp-12-10367-2012, 2012. 
Vitousek, P. M., Aber, J., Howarth, R. W., Likens, G. E., Matson, P. A., Schindler, D. W., Schlesinger, W. H., and Tilman, G. D.: Human alteration of the global nitrogen cycle: causes and consequences, Ecological Society of America, Washington, D.C., US, 1997.

Volten, H., Bergwerff, J. B., Haaima, M., Lolkema, D. E., Berkhout, A. J. C., van der Hoff, G. R., Potma, C. J. M., Wichink Kruit, R. J., van Pul, W. A. J., and Swart, D. P. J.: Two instruments based on differential optical absorption spectroscopy (DOAS) to measure accurate ammonia concentrations in the atmosphere, Atmos. Meas. Tech., 5, 413-427, doi:10.5194/amt-5-413-2012, 2012.

von Bobrutzki, K., Braban, C. F., Famulari, D., Jones, S. K., Blackall, T., Smith, T. E. L., Blom, M., Coe, H., Gallagher, M., Ghalaieny, M., McGillen, M. R., Percival, C. J., Whitehead, J. D., Ellis, R., Murphy, J., Mohacsi, A., Pogany, A., Junninen, H., Rantanen, S., Sutton, M. A., and Nemitz, E.: Field inter-comparison of eleven atmospheric ammonia measurement techniques, Atmos. Meas. Tech., 3, 91-112, doi:10.5194/amt-3-91-2010, 2010.

Whitburn, S., Van Damme, M., Kaiser, J. W., van der Werf, G. R., Turquety, S., Hurtmans, D., Clarisse, L., Clerbaux, C., and Coheur, P.-F.: Ammonia emissions in tropical biomass burning regions: Comparison between satellite-derived emissions and bottom-up fire inventories, Atmos. Environ., 1-13, doi:10.1016/j.atmosenv.2015.03.015, 2015.
Wood, S. W.: Validation of version 5.20 ILAS $\mathrm{HNO}_{3}, \mathrm{CH}_{4}$, $\mathrm{N}_{2} \mathrm{O}, \mathrm{O}_{3}$, and $\mathrm{NO}_{2}$ using ground-based measurements at Arrival Heights and Kiruna, J. Geophys. Res., 107, 8208, doi:10.1029/2001JD000581, 2002.

Yokelson, R. J., Susott, R., Ward, D. E., Reardon, J., and Griffith, D. W. T.: Emissions from smoldering combustion of biomass measured by open-path Fourier transform infrared spectroscopy, J Geophys. Res., 102, 18865, doi:10.1029/97JD00852, 1997.

Yokelson, R. J., Urbanski, S. P., Atlas, E. L., Toohey, D. W., Alvarado, E. C., Crounse, J. D., Wennberg, P. O., Fisher, M. E., Wold, C. E., Campos, T. L., Adachi, K., Buseck, P. R., and Hao, W. M.: Emissions from forest fires near Mexico City, Atmos. Chem. Phys., 7, 5569-5584, doi:10.5194/acp-7-5569-2007, 2007.

Zander, R., Mahieu, E., Demoulin, P., Duchatelet, P., Roland, G., Servais, C., De Mazière, M., Reimann, S., and Rinsland, C. P.: Our changing atmosphere: Evidence based on long-term infrared solar observations at the Jungfraujoch since 1950, Sci. Tot. Environ., 391, 184-195, 2008.

Zhu, L., Henze, D. K., Cady-Pereira, K. E., Shephard, M. W., Luo, M., Pinder, R. W., Bash, J. O., and Jeong, G. R.: Constraining U.S. ammonia emissions using TES remote sensing observations and the GEOS-Chem adjoint model, J. Geophys. Res. Atmos., 118, 3355-3368, doi:10.1002/jgrd.50166, 2013. 